\author{
Љупчо С. Ристески (Северна Македонија) \\ Институт за етнологија и антропологија \\ Природно - математички факултет \\ Универзитет „Св. Кирил и Методиј“ - Скопје \\ Е-маил: risteski@ukim.edu.mk
}

\title{
„САМО ШТО ИЗЛЕГОВМЕ ОД ОПИНЦИ, ЕТНОЛОЗИТЕ САКААТ ПОВТОРНО ДА НЕ ВРАТАТ ВО НИВ“. СТАТУСОТ НА ЕТНОЛОГИЈАТА ВО МАКЕДОНИЈА ВО ПЕРИОДОТ НА СОЦИЈАЛИЗМОТ (1946-1953)
}

\begin{abstract}
Апстракт: Во текстот се прави обид за расветлување на круцијални настани поврзани со отворањето и укинувањето на академските студии по етнографија и етнологија на Филозофскиот факултет во Скопје во периодот на раниот социјализам од 1946 до 1953 г. Во анализите се користени и архивски материјали од фондовите на Филозофскиот факултет и Министерството за образование на СРМ. Истакнати се општественополитичките услови во кои студиите се создадени и за кратко време укинати. Се укажува на општите и локаните политички и идеолошки рамки на дејствување во социјалистичката заедница. Прашањата поврзани со подемот и падот на националната етнологија во Социјалистичка Република Македонија се поврзани со идеолошките рамки за справување на социјализмот со селанството, ројализмот, назадноста, традиционализмот наспроти работништвото, комунизмот, напредокот и модерноста.
\end{abstract}

Клучни зборови: етнологија, фолклористика, Бранислав Русик, социјализам, Македонија

Во Македонија треба сѐ уште да се чекаат „поволни“ услови за реализирање на истражување насочено на историјата или поточно етнографијата на етнологијата и антропологијата како дисциплини со оглед на фактот што до сега не се направени проучувања од тој тип, а ниту, пак, се пројавени интереси од страна на државата да финансира истражување кое ќе го расветли статусот на овие дисциплини во некои периоди кои се од клучно општествено и историско значење за Македонија, а тоа се периодот помеѓу двете светски војни и периодот во времето на социјализмот ${ }^{1}$. Се

1 Авторот на текстов најмалку на два наврати, првиот пат во 2006 г. а вториот пат во 2011 г. на конкурсите за национални научно-истражавачки проекти на Министерството за наука и образование на РМ поднесуваше предлог проект чијшто истражувачки фокус беше на историјата на етнологијата во Македонија во периодот на социјализмот. Ниту еднаш не беше прифатен за финансирање. Последниот конкурс на МОН за финансирање на научно-истражувачки проекти беше објавен на 24.2.2011 г. http://www.mon.gov. 
разбира, од исклучително значење за разбирање на сегашниот статус на дисциплините е проучувањето на современите општествено-политички услови во Македонија и нејзиното окружување. До сега се напишани само неколку студии посветени на историјата на дисциплините во Македонија (Rusić 1957: 456-59; Konstantinov 1983, 1985; 1988; Паликрушева 1997; Ристески 1997, 2008; Светиева 2001, 2005, 2008). Единствен напредок во ова поле, би можело да се каже, е воведувањето на предметот Исйорија на

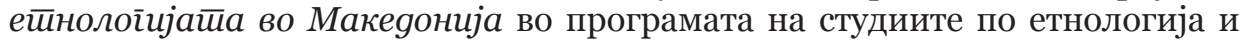
антропологија од 2005 година.

Иако, на прв поглед може да се каже дека и нема што толку многу да се истражува и пишува за статусот на етнологијата и антропологијата во Македонија со оглед на нивната, речиси, потполна изолираност и маргинализираност како дисциплини, сепак, систематското етнографско проучување може да резултира со многу интересни епизоди од историјата на дисциплините, што секогаш треба да се гледа и разбира во контекст на македонското општествено и политичко милје и поширокиот општествено политички контекст во регионот.

Разгледувајќи го развојот на дисциплините во СФРЈ, во чиишто рамки тогаш се наоѓаше и СРМ како дел од југословенската федерација, како и споредувајќ́ го статусот и состојбата со овие дисциплини во другите земји во регионот, може да се заклучи дека колку што тие имаат одредени заеднички специфичности, многу повеќе имаа различни карактеристики, претставувајќи ги сопствените национални варијанти на социјалистичко општествено уредување и стратегии на создавање на нациите (Mihailescu, Iliev, and Naumović 2008: 1-2). Општо е прифатено дека “домашните етнологии и антропологии“, без разлика на разликите во формациите на социјализмот, се нарекуваа национални gисцийлини, и како такви, некаде повеќе, некаде помалку но сите учествуваа во „создавањето на нациите“ (Mihailescu, Iliev, and Naumović. 2008: 2). Оттука, „нацијата беше во еден долг временски период политички контекст и епистемолошка рамка на однесување на сите овие 'национални етнологии'(Mihailescu, Iliev, and Naumović 2008: 2). Интересно е да се види дали кревката македонска етнологија го изгуби својот статус и исчезна од македонската општествена сцена во почетокот на 1950-те години на XX век поради овие причини? Дали македонската национална етнологија беше преголем залак и сериозен предизвик за македонското социјалистичко општество и создавањето на југословенскиот дух на братство и единство? Тука, исто така се поставува прашањето колку македонската локална академска (ис)политизирана фела го носи бремето на додворувањето кон југословенската академска и политичка врхушка во исполнувањето на идеалите на социјализмот.

Консеквентно на претходно изнесеното, фокусот на нашите истражувања ќе биде согледување на значењето и статусот на етнологијата во Македонија, како и утврдување на рефлексиите кои етнолозите како еснафска фела и етнологијата како дисциплина ги дале врз македонското општество во периодот на социјализмот. Исто така, сакаме да се расветлат влијанијата на општествените односи врз функционирањето на оваа

mk/index.php/konkursimon/717-nip2011. Како подносител на проект до 14.11.2013 г. кога е правена една од последните ревизии на текстов не сум добил никакво писмено известување од МОН во врска со предлог проектот. 
дисциплина, како во рамки на македонската, исто така и во рамки на југословенската социјалистичка заедница.

\section{Политиката и етнологијата во Македонија}

Неколку клучни фигури во антропологијата и во општествените и хуманистичките дисциплини воопшто, како што се Клифорт Гирц и Ерик Волф пишувајќи за развојот на дисциплината, укажуваат, прво, дека „има многу малку работи што се автентично автономни“(Geertz 2002: 2), и дека треба да се гледа на историјата на социјалната антропологија не само како на дисциплина што ги распространува своите идеи надвор од нејзините граници, туку и како дисциплина што е формирана во рамките на определено општествено-политичко окружување (Wolf 1999: 121). Оттука треба, првенствено, да се има предвид поврзаноста на општествената и политичката клима во продуцирањето на антрополошкото знаење во Македонија.

Намерата ни е да ги рагледуваме политиките на етнологијата во Македонија, посебно во периодот на раниот социјализам со цел да го утврдиме статусот на етнологијата во македонското социјалистичко општество и да ги согледаме нивните взаемни влијанија.

Македонија во социјалистичката југословенска државна заедница влегла како рамноправна федеративна единица што би требало да подразбира дека ги ужива сите права и ги презема сите обврски во функционирањето на заедницата. Меѓутоа, историјата на општествените и хуманистичките дисциплини во Македонија не започнла со формирањето на социјалистичката република. Етнологијата е една од првите дисциплини со кои е формиран Скопскиот Универзитет во 2оте години на XX век, како стожерна институции во реализирањето на една од најважните национални стратегии на тогашната југословенска држава, односно реализирањето на големосрпските национални идеи на територијата на Македонија, што тогаш се нарекувала Јужна Србија, а населението во неа - Јужни Срби.

Во првите години од социјализмот во Македонија, како и пошироко во целата СФРЈ интенцијата била да се расчисти со сите локални непријатели и опоненти на тогашниот режим, кои ги имало, постоеле и биле од најразлични профили. Како резултат на овие заложби, новоформираните комунистички елити, често пати, многу лесно ги етикетирале поединците, нивните семејства, па дури и генерации на ред, како непријатели или во најмала рака „неподобни“ за тогашниот систем, поради што биле онеспособувани да ги извршуваат дури и најобичните секојдневни работи. Тогаш се сметало дека комунистите и нивната идеологија во Југославија се единствената сила што може да ги запре и искорени предсоцијалистичките национални и религиозните чувства на различните заедници што учествувале во нејзиното создавање. Така, прашањата на етничноста, националните односи, национализмот и федерализмот станале централни политички, но исто така и теоретски проблеми во повоениот период (Naumovic 2008: 219).

Сепак, новиот режим се судрил со многу сериозни прашања поврзани со опстанокот на жителите и новата држава, во која биле вклучени прашањата за преструктурирањето на сопственичката 
структура и ставањето во повторна функција на делови на предвоената индустрија. Сепак, најзначајната промена се случувала во сферата на индустријализацијата на земјата, што имала круцијално значење не само во економска, ами и во идеолошка смисла. Се создавала работничка класа пролетаријатот настојувајќк, притоа, да се елиминира селанството кое било еден од најдоминантните општествени слоеви. Тоа придонесувало за нагло празнење на селата, а непланско и прекумерно зголемување на градовите. Селанството, пак, морало драстично да се редуцира со цел се создаде соодветна општествена база за пророкуваната “социјалистичка држава како држава на работничката класа“.

Првите години на социјализмот во СФРЈ се карактеризирале со цврста и груба политичка и физичка контрола на случувањата во земјата, под силно влијание на сталинистичкиот режим и социјалистичката научна мисла на CCCP (Naumovic 2008: 220-221). Како резултат на овие врски, во Југославија било забележително влијанието во именувањето и дефинирањето на дисциплината. Според советскиот модел, таа се именувала како ейноїрафија, што нашло одраз во стручната литература, како и именувањата на повеќе институции, списанија и сл. во Југославија и во Македонија. По раскинувањето на оваа цврста врска и дистанцирањето на Тито и Југославија од Сталин и СССР, настапила фазата во која се забележителни отстапувања и обиди за предефинирање на терминологијата на дисциплините и називите на институциите. Сепак, рефлексиите на ова време се забележителни во повеќе сфери до денешни денови.

\section{Селанството наспроти работничката класа, традицијата наспроти модерноста}

Историски гледано поглемиот дел од населението во Југоисточна Европа го сочинувало селанството (Encyclopedia of Easter Europe, 491492 с.в. Peasants). СФРЈ, во 1945 година, во новиот социјалистички општествен поредок влегла со речиси повеќе од 70\% селско население кое се занимавало со субзистентна економија. Оттука, слободно може да се рече дека сообразувачи на доминантната култура на тогашната нова социјалистичка заедница. Сликата за традиционалната култура на селанството во најголема мерка не соодветствувала на современите идеи и претстави за социјалистичката земја на работниците. За селанството и дотогаш биле поврзани многу идеи за назадноста, сивилото, послушноста, колективизмот и традиционалноста. Дури и во политичка смисла, селанството во кралството Југославија, главно, било поврзано со селанските партии чиишто политики биле секогаш поврзани со национализмот и ројализмот. Уште кон крајот на 19 век, селанскиот партиски аграрианизам бил заменет со национализам. Оттука, овие традиции биле на врвот на социјалистичката агенда за интензивната транзиција како застарени концепти на селанството и традиционализмот кои, пак требало да се заменат со концептите на новото време, со работништвото и модернизмот. Овие концепти се сметале за особено опасни во изградбата на современото социјалистичко работничко општество во идеолошка смисла па затоа се гледало да се маргинализираат на секој начин. Се чини дека како резултат на овој однос и етнологијата, тогаш сметана за национална gисцийлина 
која се занимава со проучување на народната култура на сите етнички и народни целини на Земјата, ги проучува законите на нивната етногенеза (Русиќ 1948) се поимала како потенцијална опасност за промовирање на некои од „традиционалните“ вредности кои требало пос секоја цена да се заменат со нови. Како резултат на ова, постепено во социјалистичката јавност почнало предност да им се дава само наодредени сегменти од народната култура, главно на фолклорната традиција, народните песни и игри, односно на фолклорот. Игрите и музиката презентирани од различни културно уметнички ансамбли станале супститут на културата на селаните во исчезнување. Претставите создадени низ адаптираните сценски изведби требало да обезбедат официјално одобрени претстави за новосоздадената нација/нации, нивната/нивните култури, како и слики за „среќните селани“.. Од друга страна, пак, елитистичкото урбано општество во создавање, на социјалистичките патриоти започнало да им сервира адаптирани форми на „народни игри“ кои требало да ги поттикнуваат чувствата на солидарност кај новосоздадената класа - работниците(Encyclopedia of Easter Europe, 178-179 с.в. Dance). Овие тенденции во CPM резултирале со укинување на студиите по етнологија во 1952 г. , и отворање на Фолклорниот Институт во 1950 г.

\section{Подем и пад на дисциплината: Личности и трендови}

Почетоците на етнологијата во Македонија во периодот по 1945 г. треба да се поврзуваат со појавата на институциите од областа на просветата и културата.

Кога се зборува за етнологијата во Македонија во периодот на социјализмот личностите кои се занимавале со неа можат да се избројат на прсти. Ова седолжи, првенствено на образовната политика во социјалистичка Македонија набљудувана во општиот југословенски концепт, каде само неколку години по создавањето на студиската група за етнографија и етнологија на Филозофскиот факултет, истата била само за неколку години укината. Така Македонија останала само со неколкуте повоени генерации дипломирани етнолози, од кои само неколкумина оставиле траги во дисциплината до денешни денови. Овде сакаме да го потенцираме фактот дека престанувањето на работата на семинарот за етнологија во 1952/53 година и непродуцирањето професионалци во дисциплината придонесло Македонија да остане на маргините на случувањата во сферата на дисциплините. Недостатокот од професионално едуцирани кадри во сферата на етнологијата и антропологијата во социјалистичка Македонија се чувствуваат до денешни денови.

Филозофскиот факултет во Скопје бил формиран во 1946 година. Во исто време е формирана и Етнолошката група или семинар под раководство на професорот Бранислав Русиќ, основоположникот на повоената македонска етнологија. Тогаш, со писмо на еден од високите политички функционери на младата македонска држава, Крсте Црвенковски, тој е поканет да учествува во етаблирањето на студиите по етнологија во Скопје. Русиќ тогаш бил вработен како асистент на Одделението за етнологија на Белградскиот Универзитет и може да се рече во многу поповолни услови отколку овие со кои требало допрва да се соочи по доаѓањето во 
Македонија. Сепак, имало реални причини поради кои Русиќ бил поканет од македонските власти да се врати во Македонија, како што, исто така, имало реални причини тој да го прифати овој предизвик, кој најверојантно го чинел многу повеќе животни и професионални одрекувања, отколку што на почетокот тој тоа го очекувал. Русиќ по род бил од Македонија, и впрочем целото негово семејство најголемиот дел од животот го поминало во Македонија. Семејството на Русиќ е едно од многуте семејства кои во периодот на балканските војни ги искусило страдањата и искушенијата на преселбите пред налетот на војните разрушувања, така што во периодот на Балканските војни, од родното село Герман во Егејска Македонија морале да се преселат неговите родители и да се населат во селата на пределот Порече во западниот дел на Вардарска Македонија. Бранислав Русиќ е роден во 1912 година во Томино Село во Порече, а подоцна семејството на Герман Русиќ, таткото на Бранислав, заедно со неговите браќа Вукашин и Светозар, и втората жена на Герман, Ленка продолжиле да живеат во Прилеп. Ѓерман во периодот меѓ двете светски војни бил познат учител во градот, а неговите синови се вбројувале во малубројните млади интелектуалци кои својата наобразба ја стекнале на Белградскиот Универзитет, а потоа се усовршувале на Универзитетите во Европа.

Кога Б. Русиќ ја започнал својата предавачка кариера на Етнолошката група на Филозофскиот факултет во Скопје се соочил со новата социјалистичка реалност на Македонија, и пошироко во Југославија. Тоа е време на ударничко создавање на новите пролетерски институции, меѓу кои и факултетите и Универзитетот во Скопје. Во одд се создавала новата социјалистичка законодавна регулатива, се создавале новите оперативни концепти, кои секогаш небиле во согласност со социјалистичката идеологија, која, исто така, со текот на времето минувала низ бурни промени, особено во периодот на првите години и годините на разврската на односите помеѓу СССР и СФРЈ.

На Етнолошката група се запишале првите студенти по етнологија, чијшто број никогаш не бил голем, а Б. Русиќ бил нивниот единствен професор по етнологија. Од наставните планови од првите години на студиите по етнологија е забележлива силната ориентација на етнологијата кон историската дисциплина, при што освен двата основни етнолошки предмета кои се изучувале безмалку во текот на целото четиригодишно универзитетско школување, сепак сите други биле од областа на историјата и археологијата.

Во периодот од 1946 до 1951 година околу 75 студенти се запишале и студирале на студиите по етнологија. Во учебната 1952/53 година, во чудни политички околности, Министерството за образование донесло одлука за укинување на студиите по етнологија со образложение дека тие според наставните планови и профилот што го продуцираат се совпаѓаат со студиите по историја на уметноста на Филозофскиот факултет во Скопје. Врз основа на оскудните архивски податоци за овој круцијален период за македонската етнологија може да се заклучи дека клучен фактор во донесувањето на одлуката за укинување на етнолошкиот семинар имале политичките заклучоци и влијанија на функционерите во Скопје кои се повикувале на банални причини за тоа: најпрво, дека конципираноста на студиите по етнологија не продуцира кадри кои ќе бидат доволно обучени за да можат да се вклучат „во оперативата“ (Записник на ОВШН, 4, јуни 
1952, ДАМ, 1012.4.7/ 96), односно примарно во образованието со цел да описменуваат што е можно повеќе неписмени граѓани на социјалистичката држава, што, впрочем било една од најважните задачи на Министерството и тогашната политичка елита, и второ, недоволната диференцираност на етнологијата од останатите дисциплини, посебно од историјата на уметност. Се разбира, овие ставови, изнесени на состаноците на Одборот за високи школи и наука при Советот за просвета, наука и култура на НРM на Министерството за образование во 1951-52 година биле пласирани од локалните политичари од Скопје кои, најверојатно, сакајќи да им угодат на писмените барања од Белград, се труделе да ги спроведуваат истите во духот на социјалистичката послушност. Од друга страна, интересна е дискусијата што се водела на состаноците на тогашниот Одбор за високи школи и наука (ОВШН) насочена кон прашањето дали студиските програми на Филозофскиот факултет треба да бидат насочени кон образување кадри за наставници, т.н. оперативци кои ќе треба да се занимаваат речиси исклучиво со описменување на населението, или ќе треба да се посветува и внимание на научната работа, од што би произлегувале поединци на кои понатаму својата професионална работа ќе им биде научната и истражувачката работа. На состаноците на кои присуствувале и претставници на Факултетот, истакнати професори какви што биле во тоа време проф. д-р Каталиниќ Марин, проф. д-р Миљовски Киро, проф. д-р Мировски Тодор, проф. д-р Атанасије Урошевиќ и други бил јасно истакнуван ставот дека не смее да се дозволи факултетите да го изгубат научниот карактер, притоа силно алудирајќи на обидите да се укинат катедрите за етнологија и за историја на уметноста. Во своето излагање тогашниот декан на Филозофскиот факултет проф. д-р Атанасије Урошевиќ, на состанокот на ОВШН одржан на 11 јуни 1952 година истакнал: „Моето мислење, другари, јас ви го изнесов уште на минатиот состанок. Сметам дека факултетот ќе го изгуби својот научен карактер ако Етнолошката група и групата - Историја на уметноста бидат укинати. Жалосно е во Македонија, која е богата со толкав етнолошки материјал, во која постои Филозофски факултет, да не постои и Етнолошка група. Истото тоа важи и за групата - Историја на уметност. Кога би ги уфрлиле овие предмети во некои други групи, тогаш ние не би добиле стручњаци од тие две гранки, научни работници, ами тие луѓе би имале само од тие два предмета. Јас ова свое мислење го застапував и н на Советот. Мое мислење е тие две групи и натаму да си останат, во кој уписот на студенти да биде ограничен, а од друга страна во најскоро време да се употполнат со наставен кадар. Сметам дека е неправилно, етнолошкиот материјал на Македонија да го испитуваат луѓе од странство, а во НРМ да не се изготвува таков кадар кога веќе пости Етнолошка група, односно група Историја на уметност." (Записник од состанокот на ОВШН при СПНК на НРМ одржан на 11 јуни 1952, 1012.4.7/ 120)

Ова значајно прашање било долго дискутирано и на една од седниците на Советот на Филозофскиот факултет, при што, како што може да се дознае од Записникот на состанокот на ОВШН, деканот на Факултетот проф. д-р Атанасије Урошевиќ ги изнел факултетските ставови пред нив: „На состанокот на Советот, кој се одржа во сабота беше поставено тоа прашање [за укинување на студиските групи, заб. Љ.Р.] и по него долго се дискутираше. Најпосле се дојде до вакво становиште: со мнозинство беше усвоено становиштето групите - Етнолошка и Историја на уметноста, да 
не бидат укинати, а по однос на нивното постоење паднаа два предлога - Првиот предлог беше - да се ограничи бројот за упис на нови студенти на дведте групи, а вториот - да се прекине со описот на нови студенти за извесен број на години. Со поголем број на гласови се усвои предлогот со кој се предлага ограничување бројот за упис на нови студенти на овие двце групи, - по пет студенти годишно“(Записник од состанокот на ОВШН при СПНК на НРМ одржан на 11 јуни 1952, 1012.4.7/ 119).

Заради комплексноста на прашањето, по предлог на проф. Блаже Конески на состанокот на ОВШН одржан на 4 јуни 1952 година била формирана посебна Комисија која ќе треба постудиозно да ги разгледа фактите и предлозите, да ги утврди позитивните и негативните страни од укинувањето на студиските групи и, потоа, Комисијата да излезе со свој предлог во врска со тоа пред Советот. Во состав на Комисијата биле членовите на Одборот: Блаже Конески, Димче Левков и Пенчо Икономов, како и тогашниот декан на Филозофскиот факултет проф. д-р Атанасије Урошевиќ (Записник на ОВШН, 4, јуни 1952, ДАМ, 1012.4.7/ 99).

Од Записниците на ОВШН е видливо дека Комисијата не успеала да изнесе еден целосен предлог, туку секој од членовите ги изнел своите лични размислувања. Од ова произлегува дека Комисијата не успеала да постигне консензус по прашањето за укинувањето или продолжувањето со работа на овие групи на Филозофскиот факултет. Според размислувањето на проф. Левков и мислењата на членовите на Советот на Филозофскиот факултет се наведува: „Прво, дека Филозофскиот факултет делимично би го изгубил научниот карактер кога би ги укинал тие две групи. Втор аргумент беше, дека Етнолошката група е национална іруйа и дека националниой

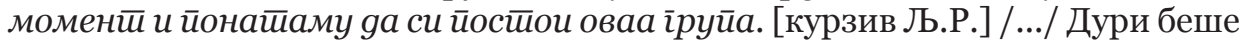
подвлечено, дека со укинувањето на овие две групи, ние земаме на себе

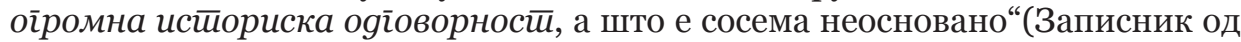
состанокот на ОВШН при СПНК на НРМ одржан на 11 јуни 1952, 1012.4.7/ 120)

Во излагањата на некои од членовите на Комисијата е забележителна доза на авторитарно однесување кон партиските власти кои настојувале овие студиски групи да се укинат. Причините за ваквите ставови на некои од членовите на Комисијата, исто така треба да се поврзат и со искажувањето, се чини, неоправдано опструирање на штотуку започнатата работа на професорот Бранислав Русиќ во Скопје. Така, професорот Левков во продолжение на својата дискусија по повод оптужбите дека одлуката за укинување на студиските групи ќе има огромна историска одговорност ја интерпретира на следниов начин: „Понатаму, неоспорно е дека е корисно од наши стручњаци да се испитува народното богатство, но со укинувањето на овие две групи не значи дека ние ќе престанеме да создадеме кадрови од таков тип. Ние тоа поле воопшто не би го запоставиле, ами дури сега, ете, оформивме Институт за народна култура. Но друго нешто, ваква каква е сега Етнолошката група, прашање е колку таа одговорила на националниот момент. Следејќи ја работата на оваа група, сметам дека на овој момент Групата на и го дала нужниот акцент. На самиот Совет [на Факултетот, Заб. Љ.P.]се осети кај луѓето страв - да ли ете и тие самите ќе останат тука или не. Ова навистина е смешна работа, затоа што ние не одиме по патот на укинување, а токму на создавање, но ако нешто укинуваме, тоа значи дека во моментот тоа што го укинуваме не е толку потребно. Затоа и сите наводи 
„дека земаме историска одговорност и сл.“ беа само обични фрази“(Записник од состанокот на ОВШН при СПНК на НРМ одржан на 11 јуни 1952, 1012.4.7/ 120-121) Така, професорот Левков, во пролетерски и социјалистички дух, прокламирајќи го „патот на создавањето“, а отфрлајќи ја „историската одговорност“ како обични фрази продолжил да го елаборира возможното укинување на студиските групи нудејќк едноставно решение, што во тоа време очигледно било во полза на тогашните центри Белград и Загреб, велејќи дека „ние би можеле таков кадар да школуваме /.../ да речеме во Белград и Загреб и богатиот материјал се пак да се испитува од наши стручњаци“(Записник од состанокот на ОВШН при СПНК на НРМ одржан на 11 јуни 1952, 1012.4.7/ 121). Како втор, особено важен момент што тој го истакнал на штета на двете студиски групи бил фактот што тие сеуште немале потполна настава. И покрај тоа што и самиот вели дека „навистина имаме и други групи, каде имаме само по еден професор, но карактерот на тие групи и потребите од кадар е таков, да ние мораме поинаку да се однесуваме кон тие групи“. Аршинот на проф. Левков во однос на студиските групи по историја на уметност и етнологија е поинаков. Така заклучил дека: „На Групата Историја на уметност го имаме само другарот Димче Коцо, а на Етнолошката - другарот Русиќ. Колку и да се напрегаат и покрај нивната добра волја, тие не можат да ги опфатат сите предавања, се разбира дека во наставата, при вакви услови, мора да има и неподготвеност, а тоа лошо се одразува врз квалитетноста во општо“(Записник од состанокот на ОВШН при СПНК на НРМ одржан на 11 јуни 1952, 1012.4.7/ 121). На официјалниот предлог на Советот на Филозофскиот факултет, проф. Левков повторно го изнел својот спротивставен став во однос на ограничувањето на бројот на студенти на 5. Повторно во духот на запоставувањето на македонските национални интереси, а во интерес на божемската економска рационализација на проблемот тој предложил: „Јас не знам дали тогаш се исплаќаат напорите на професорите да држат предавања за два-три студенти /.../ и да ли е порационално тие двајца - тројца да ги испратиме во Белград или Загреб? Јас мислам дека ова второво е поприфатливо“(Записник од состанокот на ОВШН при СПНК на НРМ одржан на 11 јуни 1952, 1012.4.7/121).

Во прилог на укинување на двете студиски групи била и личната дискусија на уште еден од членовите на Комисијата, Пенчо Икономов, кој, откако се сложил со се што било истакнато како аргументи од страна на Левков, изнесол уште еден аргумент што „таму не се зема во предвид“. „Групата Историја на уметност, каква што е таа сега, припрема исклучиво научни работници. Сите нејзини кадрови што излегуваат одат во институти каде се занимаваат со научна работа. Јас не знам каков е нивниот квалитет и во општо како се бават со наука, кога при приемот на Групата не се врши никаква селекција, а по сила на приликите сите се бават со научна работа. Зада некој се бави со наука сметам дека тој треба да располага со извесен квалитет. Истото важи и по однос на Етнолошката група. Поради тоа јас

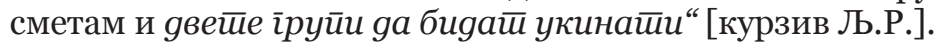

Членот на ОВШН, проф. Каталиниќ стоел на мислењето дека овие две групи и натаму треба да останат на Филозофскиот факултет „ускладувајќк го бројот на новопримените студенти со потребите на оперативата“. Како особено важен аргумент за нивно опстојување тој ги наведува следниве работи: „дека се крњи националниот момент, потреба од такви стручњаци 
во музеите“ (Записник од состанокот на ОВШН при СПНК на НРМ одржан на 11 јуни 1952, 1012.4.7/ 122)

Професорот Димче Коцо, настојувајќи да останат групите на Факултетот, нагласил дека: „штом се укинува некоја група, таа тешко се обновува“. Особено го истакнувал нивното значење од „национална гледна точка“.

Членот на ОВШН, Гојко Секуловски, кој во тоа време бил активен партиски деец и еден од политичките креатори на образовната политика во Македонија, а подоцна и Амбасадор на СФРЈ во Австралија, зазел јасен став за укинување на студиските групи, покажувајќи дури и јасен антагонизам наспроти постоењето и функционирањето на Етнолошката група. Тој, на состанокот, дури и отворено го обвинил Б. Русиќ за неговиот негативен однос во поглед на националното прашање и воопшто за целата НР Македонија. „Натаму, професорот Урошевиќ истакна дека нашето богатство не би требало да го испитуваат страни стручњаци, ами наши. Јас сметам дека е потребно да видиме колку такви стручњаци кај нас дошле и колку на тие стручњаци нашиве групи им помогнале? Јас можам слободно да кажам, дека постоењето на Етнолошката група досега негативно влијаела / другарот Гојко при тоа зборуваше за негативниот однос на Русиќ во општо по националното прашање и конкретно за НPM/ Тргнувајќи оттука продолжи другарот Гојко - не би имало ни смисла повеќе да се говори во одбрана на постоењето Групата Етнологија. Оние работи што ги изнесов за Русиќ не сакам да се сметаат како аргумент, но сакам да кажам дека постоењето на Групата досега влијаело само негативно, а никако позитивно.

Каква потреба ние имаме од етнолози? Сметам дека Левков правилно се изрази по тоа прашање. Потребите од етнолози во нашата Република се минимални и секогаш тие ќе бидат такви. Спрема моето мислење, и во далечна перспектива /за околу 10 год./ нам нема да ни бидат потребни повеќе од 19 етнолози. Тоа значи дека и во тој поглед погледнато, Групата е неодржлива.

Сметам дека треба да обрниме внимание и на овој момент - и самите студенти не ја поштуваат оваа Група, ја потценуваат. И они што излегле работат некоја сосема друга работа, со исклучок на инеи што работеле во некој музеј.“ (Записник од состанокот на ОВШН при СПНК на НРМ одржан на 11 јуни 1952, 1012.4.7/ 122-123)

Во контекст на посакуваното пролетерско, младинско однесување, Секуловски Гојко, алудирајќи на некаква реакционерна и прозападна ориентираност на студентите ги нарекува „мамини мази од Скопје“ ((Записник од состанокот на ОВШН при СПНК на НРМ одржан на 11 јуни $1952,1012.4 .7 / 123)$. И тој сметал дека оние кои сакаат да студираат тоа може да го направат во Белград и Загреб.

Во дискусијата на состанокот на ОВШН се вклучил и Димче Мире, кој исто така, во духот на социјалистичкиот напредок и социјалистичките вредности да се оди напред, а не назад, сметал дека Етнолошката група му го намалува реномето на Филозофскиот факултет. „Ние навистина имаме потреба од етнолози, но тоа не значи дека ние не можеме да создадеме добри етнолози на факултетот во Белград или во Загреб. На нашава група ни доаѓa секој, а таму би ги испратиле најдобрите, оние кои ние ќе іи избереме [курзив Љ.Р.]“. 
Така, Димче Мире својот предлог во однос на разрешувањето на прашањето со двете студиски групи предлага да се разреши на следниов начин: „Етнолошката Група и Групата Историја на уметност да се укинат, но предметот Историја на уметност да биде застапен во Историската група /.../ По однос на Етнологијата предлагам во Групата Географија да внесеме Етнологија“(Записник од состанокот на ОВШН при СПНК на НРМ одржан на 11 јуни 1952, 1012.4.7/ 124).

На крајот на дискусијата по овие прашања, претседателот на состанокот другарот Славко Поп Антовски резимирал: „Од излагањето на мнозинството излегува дека овие две групи - Етнолошката и Историја на уметноста, треба да се укинат, и тоа, во прва година да не се примаат нови студенти, втора година да се преориентира, а III и IV година да си завршат по своите групи..."(Записник од состанокот на ОВШН при СПНК на НРМ одржан на 11 јуни 1952, 1012.4.7/ 124).

По затворањето на студиите по етнологија, но не и на студиите по Историја на уметноста, етнологијата како предмет била доделена на студиите по географија, а професорот Бранислав Русиќ, целосно маргинализиран.

\section{Етнологијата и фолклористиката - непродуктивна компетитивност}

Разгледувајќи ја историјата на дисциплините во Македонија и нивното институционализирање, се чини, дека политичките влијанија на новиот социјалистички режим и на комунистичката партија имале круцијално значење. Овие влијанија, како што погоре беше изнесено, се јасно забележливи во однос на прашањето за краткотрајниот живот на универзитетските студии по етнологија во Македонија и донесувањето политички решенија за нивно укинување. Се разбира, политиката наспрема културното наследство, народната традиција и други општествени аспекти на секојдневното живеење се огледаат и во процесот на донесување политички одлуки во однос на формирањето на Фолклорен Институт, а денес Институт за фолклор „Марко Цепенков“ - Скопје.

Кон крајот на четириесеттите години на XX век во Македонија се размислувало за создавање на научно-истражувачки институции со цел стручно, систематско и севкупно истражување и заштита на етнолошкото и фолклорното културно наследство.

Врз основа на архивските материјали со кои располагаме, може да се утврди дека професорот Бранислав Русиќ, кој во тоа време бил единствениот професор по етнологија во Скопје, бил една од најзначајните личности вклучени во создавањето на концептот за структурата и научната компетентност на идната истражувачка институција. За Б. Русиќ било повеќе од јасно дека новата истражувачка институција треба да биде што е возможно пошироко ориентирана кон проучувањето на народната, традициска култура, како основа за разбирањето на сегашноста на македонското современо, социјалистичко општество. Оттука, тој алудирал да се создаде Институт за проучување на народната култура, или Институт за народна култура, Институт за Македонска народна култура, Институт за народна култура на НРM, или пак, во најмала рака Етнолошки Институт. 
Од архивските документи поврзани со изготвувањето неколку различни варијанти Правилници за организација и работа на новата истражувачка институција може да се забележи дека, најверојатно, прво од именувањето на новата институција била исфрлена придавката македонска, што укажува на дистанцирањето од било какви обиди за давање „национален“ предзнак на институцијата. Се чини, во процесот на креирањето на културната политика во НРМ во раниот социјализам, целта била акцентот на истражувањата да се стави на културата, отколку на етничките, националните и на другите општествени аспекти на живеењето, како во минатото, така и во сегашноста.

Во една од варијантите на Правилникот за организацијата и работата на Институтот за Македонска народна култура, уште во членот 1 се предлага својата работа да ја заснова „на територијата на Народна Република Македонија и на другите републики“, алудирајќи на истражувачка работа во рамките на државните граници на СФРЈ и административните граници на југословенските републики. Овој став би можело да се интерпретира и како обид за затворање на прашањето во однос на евентуалните истражувачки потфати на институтот во соседните земји каде што живеело население поврзано со Македонија (Правилник..., ДАМ, Фонд 1370, Министерство за просвета, наука и култура 1951-1951; 1.1370.1.28/123).

Во Членот 2 како основни задачи на идната институција се предвидува да бидат:

1. „Да ја организира работата на собирањето, систематизирањето и конзервирањето на фолклорното богатство на македонскиот народ;

2. Да го научно анализира, прочистува и обработува собраниот материјал од подрачјето на народната култура;

3. Да дава совети и стручни мненија во врска со применувањето на нашата народна уметност во домашните ракотворби, музиката, индустријата, градежништвото и т.н.

4. Да соработува со организации, друштва и установи кои што работат на пропагирањето на нашата народна уметност од територијата на ФНРЈ и во странство и да се грижи за чистоката и изврсноста на нашата народна уметност;

5. Да се грижи за запазување и понатамошно развивање на нашето народно уметничко творештво;

6. Да издава научни и научно-популарни публикации од областа на својата работа.

(Правилник..., ДАМ, Фонд 1370, Министерство за просвета, наука и култура 1951-1951; 1.1370.1.28/123).

Од листата на наброените основни задачи на Институтот се забележува дека се предлагало акцентот на дејствувањето да биде во сферата на фолклорното богатство и народната култура, при што, посебен акцент се става на народната уметност. Во следните верзии на правилникот, од алинејата 1 е исфрлен зборот „на македонскиот народ“, најверојатно, со цел да не се навлегува во прашања кои можело да предизвикаат реакции во контекстот на југословенската федерација, а можеби и внатре во Македонија, а научните истражувања да останат со предзнакот на „домашни“ 
и ,југословенски“ но никако како „национални“ и „македонски“ во духот на создавањето на современата, социјалистичка македонска нација.

Интересно е што доста висок приоритет на новата истражувачка институција се предлагало да се даде на нејзината општествено прифатлива и применета активност во сферата на аплицирањето на традиционалните вредности на народната уметност врз современите форми на народното и на индустриското производство па дури и во современото градежништво.

Во слична насока се предвидувало да се формираат 6 (шест) стручни одделенија на Институтот:

1. Одделение за народна архитектура;

2. Одделение за народни обичаи;

3. Одделение за народна книжевност;

4. Одделение за народни игри и ора;

5. Одделение за народна музика;

6. Одделение за народна уметност, орнаментика, резбарство, живопис, вез и сл.

(Правилник..., ДАМ, Фонд 1370, Министерство за просвета, наука и култура 1951-1951; 1.1370.1.28/126).

Бранислав Русиќ од самиот почеток се противел на идејата за создавање Фолклорен Институт со оглед на фактот што сметал дека на тој начин, со ставање акцент на фолклорот, научно - истражувачката работа на институцијата значително ќе се стесни. Истражувањето на фолклорот, Русиќ го гледал како домен на еден од одделите што евентуално би се отвориле во рамките на институт со поширок истражувачки опсег.

Во јавната дебата што започната да се води дури и низ преписки во тогашните гласила на НРМ, а што не било својствено за времето на раниот интервенционалистички социјализам, Русиќ јасно стоел на позицијата дека еден таков истражувачки институт треба истражувачки да ги опфати сите аспекти на народната култура, а во никој случај акцентот да се стави само на фолклорот. Всушност, во овој период во Македонија се наметнала една неприродна дискусија за местото и улогата на етнологијата и фолклористиката, што била пренесена од другите југословенски простори исто така, а била директно поврзана со некои од идеолошките и политичките гледишта за евентуалните реперкусии што може да ги имаат етнологијата и фолклористиката на развојот на современото социјалистичко општество. Мора да се признае дека на фолклористиката се гледало како на помалку „опасна“ во поглед на отворањето и евентуалното разгорување на некои од се уште горливите национални и етнички прашања, бидејќи таа била повеќе ориентирана само кон одредени сегменти на народното творештво, кое лесно можело да се интерпретира како богатство, ресурс кој е вредно да се чува и заштитува (Ристески 1997: 49-50).

Така, како резултат на непродуктивната компетитивност помеѓу етнологијата и антропологијата произлегла тенденцијата фолклористиката да се протежира како функционален еквивалент на поранешните национални дисциплини, но со поблаго влијание. Резултатот од ваквиот непродуктивен натпревар, во македонски рамки, било создавањето на Фолклорниот институт, каде што етнологијата била претставена само со едно Одделение за народни обичаи и игри. Ова јасно го покажува јасното дистанцирање на македонската официјална политика во периодот од 
раниот социјализам од евентуалното отворање на било какви прашања од национален интерес на Република Македонија. Како што може да се види од концептот на Институтот, игнорирани се сите истражувачки аспекти на идентитетот, прашањето за потеклото на заедниците, како и било кои други прашања поврзани со мнозинската македонска или другите малцински заедници во неа.

И покрај долгогодишните дискусии и јавни дебати што Б. Русиќ како претставник на етнолозите ги водел во Македонија во периодот од 1950 до 1954-55 година со претставниците на фолкористичката дисциплина и нивните политички приврзаници, се чини, дека тој слично како и со студиите по етнологија така и во однос на дефинирањето на научниот карактер на Институтот ја изгубил битката.

\section{Заклучок}

Разгледувајќи го развојот на етнологијата како дисциплина во социјалистичката федерација може да се заклучи дека етнологијата колку што има одредени заеднички специфичности со статусот во другите републики на тогашна СФРЈ, многу повеќе има различни карактеристики, претставувајќи ги сопствените национални варијанти на социјалистичко општествено уредување во СР Македонија. Општо е прифатено дека “домашните етнологии и антропологии“, без разлика на разликите во формациите на социјализмот, се нарекуваа национални gисцийлини, и како такви, некаде повеќе, некаде помалку но сите учествуваа во „создавањето на нациите“. Оттука, „нацијата беше во еден долг временски период политички контекст и епистемиолошка рамка на однесување на сите овие 'национални етнологии'. Интересно е да се види дали кревката македонска етнологија го изгуби својот статус и исчезна од македонската општествена сцена во почетокот на 1950-те години на XX век поради овие причини? Дали македонската национална етнологија беше преголем залак и сериозен предизвик за македонското социјалистичко општество и создавањето на југословенскиот дух на братство и единство? Тука, исто така се поставува прашањето колку македонската локална академска (ис)политизирана фела го носи бремето на додворувањето кон југословенската академска и политичка врхушка во исполнувањето на идеалите на социјализмот.

Првите години на социјализмот во СФРЈ се карактеризирале со цврста и груба политичка и физичка контрола на случувањата во земјата, под силно влијание на сталинистичкиот режим и социјалистичката научна мисла на СССР. Според советскиот модел, таа се именувала како eйноїрафuja, што нашло одраз во стручната литература, како и именувањата на повеќе институции, списанија и сл. во Југославија и во Македонија. По раскинувањето на оваа цврста врска и дистанцирањето на Тито и Југославија од Сталин и СССР, настапила фазата во која се забележителни отстапувања и обиди за предефинирање на терминологијата на дисциплините и називите на институциите.

Како резултат на овој однос и етнологијата, тогаш сметана за национална gисцийлина која се занимава со проучување на народната култура на сите етнички и народни целини на Земјата, ги проучува законите на нивната етногенеза (Русиќ 1948) се поимала како потенцијална опасност 
за промовирање на некои од „традиционалните“ вредности кои требало по секоја цена да се заменат со нови. Како резултат на ова, постепено во социјалистичката јавност почнало предност да им се дава само на одредени сегменти од народната култура, главно на фолклорната традиција, народните песни и игри, односно на фолклорот. Игрите и музиката презентирани од различни културно уметнички ансамбли станале супститут на културата на селаните во исчезнување. Претставите создадени низ адаптираните сценски изведби требало да обезбедат официјално одобрени претстави за новосоздадената нација/нации, нивната/нивните култури, како и слики за „среќните селани“.

\section{Извори}

Записник на Одбор за високи школи и наука (ОВШН), 4, јуни 1952, Државен Архив на Македонија (ДАМ), 1012.4.7/ 96

Записник од состанокот на ОВШН при Советот за просвета, наука и култура (СПНК) на Народна Република Македонија одржан на 11 јуни 1952, ДАМ, 1012.4.7/ 120)

Правилник за организацијата и работата на Институтот за Македонска народна култура, ДАМ, Фонд 1370, Министерство за просвета, наука и култура 1951-1951; ДАМ, 1.1370.1.28/123

\section{Литература}

Константинов, М. 1985. „Етнологијата на Македонија во современиот миг“. Гоgишен зборник: Геоірафија 29: 201-209. Скопје: Институт за географија, Природно -математички факултет, Универзитет „Кирил и Методиј”.

Константинов, М. 1988. „Постигања на македонската етнологија“, Предавања на XX семинар за македонски јазик и култура на Универзитетот “Кирил и Методиј” (Скопје - Охрид, 7-27 јули 1987). 271-286. Скопје: Универзитет “Кирил и Методиј”.

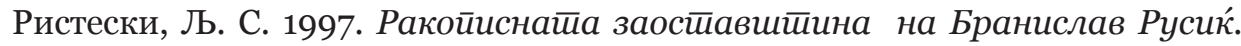

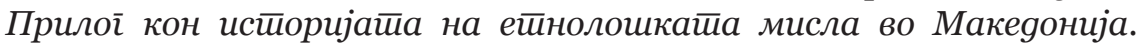
Битола: “Мисирков”.

Русиќ, Б. 1954а. Дискусија околу Фолклорниот институт. Нова Македонија XI: 11.

Русиќ, Б. 1954б. Етнографија или етнологија. Зборник Матице Српске, Бр.VIII, Нови Сад, 55-66. 
Русиќ, Б. 1955. Едно појаснување (во врска со дискусијата за Фолклорниот институт). Нова Македонија II: 8.

Русиќ, Б. 1957, Bericht über die ethnologisch Arbeit in der VR Mazedonien (19451955). Südost Forschungen XVI: 156-159.

Русиќ, Б. 1959. Odredba pojma folklora. Rad Kongresa Folklorista Jugoslavije u Varaždinu 1957, Savez Folklorista Jugoslavije, pp. 271-273. Zagreb.

Русиќ, Б. б.г. „Етнологијата и нејзината должност во Македонија“. Архив на MAHУ, К-1, AE 61-1-6 (ракопис).

Русиќ, Б. б.г. Антропологија Македоније. Архив на МАНУ, К-1, АЕ 6о, 1-5(ракопис).

Русиќ, Б. б.г. Етнологија. Архив на МАНУ, К-1(ракопис).

Светиева, А. 2001. „Статусот на етнологијата на Универзитетот “Св. Кирил и Методиј” во Скопје“, Реферат претставен на бугарско - македонска конференција: "History and Education”, Sofia, 8-9 June 2001, ракопис.

Светиева, А. 2005. „Конечно Институт за етнологија и антропологија на Универзитетот „Св. Кирил и Методиј“ - Скопје, Природно математички факултет“, Ейнолог̄ 11: 225-232, Скопје: Македонско етнолошко друштво.

Encyclopedia of Eastern Europe. 2000. From the Congress of Vienna to the Fall of Communism, Ed. by Richard Frucht (Garland Reference Library of Social Science), Routledge.

Geertz, Clifford. 2002. The Politics of Culture, Asian Identities in a Splintered World. Misuzu Shobo.

Konstantinov, M. 1983. 'Etnologija u Makedoniji'. Bo: Zbornik 1 Kongresa jugoslovenskih etnologov in folkloristov 1. 88-94. Ljubljana: Savez udruženja folklorista Jugoslavije.

Mihailescu, V., I. Iliev, and S. Naumović. 2008. Studying Peoples in the People's Democracies: Socialist Era Anthropology in South-East Europe. Berlin: LIT Verlag. 
Naumović, S. 2008. 'Brief Encounter, Dangerous Liaisons and Never-ending Stories: The Politics of Serbian Ethnology and Anthropology in the Interesting Times of Yugoslav Socialism'. In: Studying Peoples in the People's Democracies: Socialist Era Anthropology in South-East Europe, Eds. Vintila Mihailesky, Ilia Iliev, Slobodan Naumović. 211-26o. Berlin: LIT Verlag.

Palikruševa, G. 1997. 'The Development of Macedonian Ethnology and Folklore'. Ethnologia Balkanica 1: 214-217.

Risteski, Lj. S. 2004. 'The Achievements of Ethnology in Investigating Folk Religion and Mythology in Macedonia'. In: Ethnology of Religion. 175-190. Budapest: Akademiai Kiado.

Svetieva, A. 2009. 'On Macedonian Ethnology and the work of prof. Gjorgji Zdravev, Ph.D.', Bo: Social and Spiritual Aspects of Material Culture, 1317. Skopje: Institute of Ethnology and Anthropology, Faculty of Natural Sciences and Mathematics, "Ss. Cyril and Methodius" University in Skopje.

Wolf, Eric (with Sydel Silverman). 2001. Pathways of Power: Building an Anthropology of the Modern World. University of California Press. 